\title{
The Effectiveness of Think Talk Write Model in English Essay Writing
}

\author{
Febriyantina Istiara ${ }^{1}$ \\ Istiarafebri02@gmail.com ${ }^{1}$ \\ Pendidikan Bahasa Inggris Universitas Esa Unggul, Indonesia ${ }^{1}$
}

\begin{abstract}
The aim of this study is to examine the effect of think talk writes learning model on English essay writing ability of English Education Program Study at STKIP Bandar Lampung. The research sample was 22 semester IV students. The process of collecting data through observation, interviews and tests. The technique of data analysis is t-test independent. While the process of data validity used credibility, transferability, dependability, and conformability. The results of the research show that the mean of the pre-test was 52.2 and the mean of post-test was 76.9. While the t-test result was 8.566. It shows the differences in students' English essay writing ability before and after using think talk write learning model.
\end{abstract}

Keywords: Essay, English, Think Talk Write Learning Model, Writing

\section{Introduction}

Writing skills are still considered the most difficult skill to learn in the class, especially essay writing learning that requires understanding in making many paragraphs. Richards and Renandya, [1] stated that writing skills are the most difficult thing, especially for second language students. Difficulties not only lie in generating and managing ideas but also in translating ideas into the readable text. Writing skills are very complex. Second language writers must pay attention to higher level skills from planning and organizing as well as to basic level skills from spelling, punctuation, word choice, and so on.

Anker [2], stated that the essay is a piece of writing that examines a topic in more depth than a paragraph. Shorts essay may have four or five paragraphs, totalling three hundred to six hundred words. A long essay is six paragraphs or more, depending on what the essay needs to accomplish - persuading someone to do something, using research to make a point, or explaining a complex concept. Meanwhile, Zemach and Rumisek[3] said "an essay is a group of paragraphs about one topic and one main idea of the mind. Essays have at least three paragraphs, but five-paragraph essays are often used in academic writing." So, the essay is an activity to write many meaningful paragraphs. An essay is a long series of paragraphs that have meaning. Folse, Vokoun and Solomon that, "essays are short of collections that present facts, opinions, and ideas about a topic."[4] Essay format consists of five paragraphs, including the introductory paragraph to explain the topic, two paragraphs or the development 
of four paragraphs to explain the topic more clearly and paragraph five are paragraphs of conclusions. So, the essay is built from several paragraphs that develop ideas or topics discussed. The first step in writing an essay is to analyze the essay learning about the topic to be used and also give an indication of the types of things expected in accordance with the topic. Essay topics have 3 components, among others; 1) clear words, say about what will be done, 2) main keywords that describe the topic, and 3) words that explain aspects of the topic.[5] the essay must have a planning structure. Because the essay has three main parts, among others; 1) opening paragraph, 2) development or body of paragraphs and 3) paragraphs of conclusions. [6]

Writing has different purposes for students in high school and university. In the high school, writing learning consists largely of developing discipline in your approach to studying and building up a body of knowledge that will prepare you for the outside world - both the social world and the world of work - and for the studies, you may choose to undertake as an undergraduate student. In contrast, university education exists to build on that foundation with a view to further developing your intellect and powers of analysis, your specialist knowledge of the subject you have chosen to study and your ability to play a role in taking forward that field of study through your own ideas and creativity. It shifts as you move from high school to university that is reflected in the expectation tutors have your writing.[7] It can be concluded that students in college need more comprehension of knowledge about an essay, like as Murray explained. But the ideal conditions have not been realized in accordance with the expectations of the English language study program STKIP Bandar Lampung. Because there is some problem in essay writing learning.

Observation results explained that students copy the text from the book and report it as a writing assignment. It shows, they are not doing writing activities but only copying and records. Writing requires packaging, structuring, and developing ideas and ideas from the author. The low ability of students in writing is also caused by the learning approach applied by lecturers is not in accordance with the material being taught. Generally, the method used emphasizes teacher centred interaction between lecturers and students. Other problem of students' essay writing learning seen in; 1) less able to understand the concept of cohesion and coherence, 2) lecturers have not used a varied learning model, such as Think Talk Write learning models, and 3) students still have difficulty understanding the essay structure.

From the observations of researchers, the learning model applied so far is a general learning model by relying on lecture and discussion models. This model only focuses on lecturers without paying attention to the learning needs of writing essays. In the lecture learning model, students tend to only receive material from lecturers and are not active to develop material. Although it has been combined with discussion, students still remain less active. Thus, the learning model used so far has not fulfilled the needs of practice such as think talk write learning models.

Based on these problems, the learning process of writing essays requires a learning model that is able to meet the needs of students in writing essays. Learning models that provide opportunities for students to be able to process critical mindsets. Because writing essays require extensive imagination. Therefore, the learning model of think talk write offers a different learning concept for class writing essays. Think-Talk-Write (TTW) model is a learning model that terrorizes students to think, speak, and then write a particular topic. This strategy is used to develop writing smoothly and train the language before writing. The thinktalk-write strategy allows students to influence and manipulate ideas before writing them in writing. This strategy also relies on developing thinking skills, verbal and written communication. Students are directly involved in thinking or dialogue with themselves 
through the reading process and continued by sharing information among friends before students write ideas into writing.

TTW strategy builds student essay writing skills is easier because of its advantages and disadvantages. The superiority of TTW is like teaching students more confidence in their abilities, improving thinking, reading and writing, making students who have low abilities become more active, and able to develop their ideas. Whereas weaknesses such as teachers must provide a lot of time to explain TTW, it is difficult to form a complete collaboration, and students are ashamed to express their opinions. The implementation of TTW strategy had an impact on improving the ability to write descriptive text. [5]

Different views are still related to thinking talk write strategies, there is a talk-write model which is a proposal for cognitive writing models. This model was developed by Robert Zoellner in January 1969. Gary Hatch and Margaret Walter (about Zoellner's talk writing pedagogic) [8] that Zoellner first discussed writing as the process of completing a product. The Zoellner model also relies on the interaction of students with teachers or students with instructors and the participation of other students, expecting renewable discussion about writing as a social activity. The purpose of this model is to make students want to say their views, receive direct reactions from teachers and other students, and write and rewrite the spoken words to convey listeners indicating that communication is effective. Two strategies in learning basic writing at the University of Washington invaded that; a) "What I Think, I Can Say, I Can write," and b) "The Sounds in What I Say Are Related to Letters in the Words I Write." Jennifer Katahira, a teacher who is an expert in integrating teaching reading-writing, implementing this strategy in the initiated research project, and the university research team offers an evaluation component. He demonstrated the first strategy every day including; a) by thinking, the ideas discussed are what is planned to be written and what is being discussed, b) with a different model that he can express ideas, and c) with a model of how he can say each word. [9]

Thus, the study focus on the improvement of English essay writing using think talk write learning model. Based on the problem above, the formulation of the problem in this research as follows; how is the result of enhancing English essay writing learning through think talk write learning, model?

\section{Methode}

\subsection{Methods}

The method of study used an action research method. It is a mixed method that combined qualitative and quantitative research. The qualitative study is for the learning process in the class and the quantitative study is taken in the essay writing score (pre-test and post-test).

\subsection{Participant of Research}

The participant of the research are the fourth-semester students consists of a total of 22 students English Education STKIP Bandar Lampung.

\subsection{The process of Collecting Data}

The process of collecting data are 1) observation is used to identify the essay writing problem in the preliminary research and learning process in the class; 2 ) interview is taken teacher and 
students; 3) documentation is used to know the result of students' learning; and 4) the test is taken from pre-test and post-test.

\subsection{The technique of Data Analysis}

The technique of data analysis used t-test independent to know the difference between students' essay writing ability before and after using think talk write learning model. While the process of data validity used credibility, transferability, dependability, and conformability.

\section{Finding and Discussion}

Based on data that collected from respondents as many as 22 students are known the differences in score test between pretest and posttest. Here is the result of data analysis;

Table 1. The result descriptive statistic of essay writing test

\begin{tabular}{c|cc}
\hline Account & 1148 & 1692 \\
\hline Mean & 52.2 & 76.9 \\
Median & 55 & 77.5 \\
Standard Deviasi & 6.6 & 3.7 \\
Maximum Score & 62 & 82 \\
Minimum Score & 40 & 70 \\
Variant & 184,1 & 13.6 \\
\hline
\end{tabular}

The table above shows that the post-test score of English essay writing skills using thinktalk-write (TTW) learning model obtained the highest score of 82, the lowest score of 70, the average value of 76.9 , the median value 77.5 , and standard deviation 3.7 . While the pre-test score obtained the highest score of 62 , the lowest score of 40 , the average value of 52.2 , the median value 55, and a standard deviation of 6.6. If the data compared with the pretest, it is known that the posttest score has increased. It can be concluded that students' English essay writing ability has improved when they taught using a learning model that is appropriate for their needs.

While the result of t-test can be seen that $t$-account (8.566)>t-table (1.717), which means Ho is rejected and $\mathrm{H} 1$ accepted, so it is known that the use of think talk write learning model can increase English essay writing ability significantly. The increasing of each students' score can be seen from the graph below; 


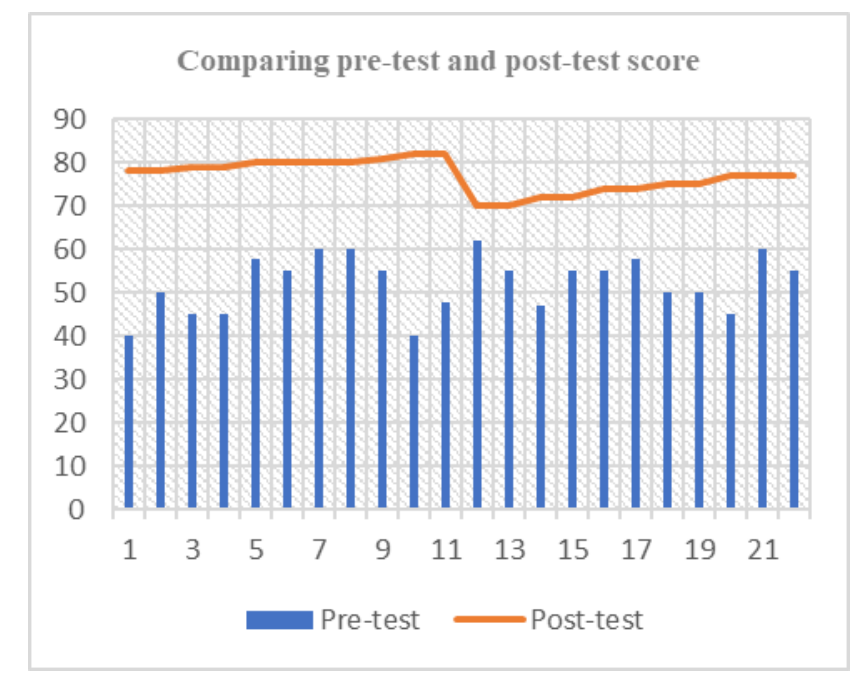

Graph 1. The Increasing English Essay Writing Test

Think Talk Write learning that is applied to students is by peers learning. Students exchange new information, ideas or topics in developing essays (speaking) so as to stimulate students' critical thinking patterns. Students can easily write down their ideas with input. Learning using Think Talk Write is very dependent on the ability of students and their peers. Colleagues strongly support the success of learning with this learning model. The learning process is carried out collaboratively through the development of tasks (forming a pattern or mind mapping) and the integrity of speaking skills contained in writing through think talk write patterns.

In the first cycle, this learning directs students to understand the topic and determine the main ideas that will be the main thought idea (thesis statement). This section guides students to do the mapping. When writing essays, of course, students must run the main process in the writing process. In the second cycle refers to the development of tasks that will be carried out by students. In the process of learning essay writing, students begin to develop the main ideas into several paragraphs with the use of good and correct language in order to get meaningful writing. The third cycle gives students the opportunity to re-check the task at hand. After the student completes his essay, the next process as the last process is to re-edit the writing as a whole both related to grammatical, the use of the word to the integrity of the meaning.

The application of think-talk-write learning in teaching essay writing involves five components, namely the teacher builds a desire for the mutual need for each other. In this case the need to develop ideas or topics that they have. The students working with partners ask each other for help and improve their attitude towards writing. They will show a high level of enthusiasm, curiosity and involvement in being taught through cooperative learning tasks. Thus, an incorporation of these activities will be of great benefit to the student community and help them enhance their writing skill.[10]

The second stage is the reciprocal process, in this case, there is discussion or information sharing to develop their topic. The third stage is the group process, namely, the lecturer gives the right time and procedure to students in analyzing the data supporting their ideas or topics. After that, it is continued in the fourth stage, which is determining the trust in the information provided by other students and determining or selecting the right information. The last stage, 
the teacher provides opportunities for students to build communicative interactions to develop essays.

So the think-talk-write learning process is carried out through 4 stages so that students' critical thinking skills can be managed appropriately. Teachers must be able to build the basic abilities of groups that are owned by students through the basics of mutual need, namely the formation of discussion groups. The next step is to manage the ability of individual activities to complete the tasks they have by sharing opinions with colleagues (expressed verbally). The third stage is building an understanding of the material to be studied. Furthermore, the fourth stage is to develop critical thinking of students to be more developed through writing.

Some research has proven the significance of the think talk write strategy in writing learning. This strategy has a relationship with the cooperative strategy. Cooperative learning approach for the instruction of essay writing is very effective than the conventional methods especially rote learning under the strict discipline of the lecturer. It makes the class a studentcentred where they can discuss, share and construct their own sentences of varied structures.[11] Therefore, writing learning needs self-concept. Like as Fatimawati found in her research that in the academic writing class. Overall, this study demonstrated that an L2 learner's self-concept in academic writing is complex and multifaceted. [12] Linguistic intelligence, which was claimed to be the main factor responsible for second or foreign language skills (Gardner, 1983), turned out to be less significant to? the token rate of logical connectors in EFL essay-writing than the logical intelligence, though the students with higher linguistic intelligence possibly tend to avoid repetition in using logical connectors. [13] Writing is a tool for assessing and promoting student understanding and independent thinking on the specific subject matter; they seek to give developing students the same experience of "writing to learn." Writing is integrated with reading, listening, and discussion about the core content and about collaborative and independent research growing from the core material. Several published reports on writing and academic skills surveys include data on types and relative frequency of writing tasks in various academic fields. [14]

Writing is basically about how we can make meaning, at the same time, a way for writers to participate in building new knowledge. When writing, there are two things done by the author, namely "saying knowledge" and "changing knowledge" so that it becomes knowledge. It takes some knowledge and skills to make it happen. English essay writing skills related to the ability of students to assemble several paragraphs into writings that are many and have meaning. The finding of this research is related to the improvement of essay writing skills. Essay writing skills are a process of developing thinking and the power of interpretation of a topic by developing ideas into valuable and meaningful writing. Essay writing skills that students must master relate to aspects found in real life and classroom learning. English essay writing skills developed in this research relate to the competency improvement process that is owned by each student to perform cognitive, affective and psychomotor activities which are written through essay writing.

English essay writing skills related to the ability of students to assemble several paragraphs into writings that are many and have meaning. Based on the description of these theories, the synthesis of this research is related to the improvement of essay writing skills. Essay writing skills are a process of developing thinking and the power of interpretation of a topic by developing ideas into valuable and meaningful writing. Essay writing skills that students must master relate to aspects found in real life and classroom learning. English essay writing skills developed in this research relate to the competency improvement process that is owned by each student to perform cognitive, affective and psychomotor activities which are written through essay writing. 
Think Talk Write learning has advantages, namely; 1) students are not saturated with learning because they are done together because of the stimulation of ideas from peers. 2) Helps stimulate students' critical thinking patterns through information provided by peer care. 3) There is an equal opportunity to share ideas or topics and accept new ideas or topics in developing essays (speaking). 4) Students have a place to ask questions through peers which can erode shame rather than asking the lecturer when having difficulty developing paragraphs. 5) Students can easily write down their ideas with input or input from peers.

While the weaknesses of the think-talk-write learning model are; 1) giving students the opportunity to talk about other things when they don't enjoy the class discussion. 2) There is a difference of opinion about something that is trivial and insignificant which makes the discussion process run long or something goes wrong. 3) Group errors can occur, that is, if there are students who are not right in giving concepts or information, it will result in errors in completing essay assignments. Therefore, lecturers must utilize or provide rules for the completion of essay writing assignments.

The success of a learning model is also influenced by all elements in the education environment, not only teachers but students, facilities, the accuracy of learning design, stakeholders, environment, parents and so on. Because all these elements constitute a complete unity in improving the quality of education. Like in the writing learning process. When designed with the right method and collaboration between all elements of education actors will produce writing skills that are of a quality. Thus, think-talk-write learning models can be applied to groups of students who have high critical thinking patterns. The application of the model to the essay writing course at STKIP PGRI Lampung provides problem-solving for diverse groups of students in critical thinking.

\section{Conclusion}

The result of data analysis shown that students have increased their English essay writing. It is seen in the differences test score before and after using think talk write learning model. The use of think-talk-write (TTW) learning models, researchers must be good at managing the class when the group discussion process takes place and provide an understanding of the procedures for implementing think-talk-write (TTW) because when implementing think-talkwrite (TTW) in group discussions students often chat with friends. In addition, there are still students who just keep quiet and wait for their friends to complete the task. So, the teacher as a researcher must be able to organize the class carefully. This is a big challenge when implementing learning.

The results of this study provide recommendations on English essays writing learning. The choice of think-talk-write (TTW) learning model can be used as a guide for lecturers to develop the use of cooperative learning models in the classroom. Lecturers can use this model in basic or advanced writing courses. If you see the effectiveness of the results of this research can help improve writing skills. Moreover, the characteristics of students in STKIP Bandar Lampung have the same level. However, if the lecturer is more creative then this learning model can be applied to other courses or combined with other learning models or the use of other learning strategies. For universities. The results of this study can be used as part of improving the English language skills of students in the English study program. Because the progress of a study program can be seen from the ability of each student. 


\section{References}

[1] J. Richards, A. C., and W. A. Renandya, Methodology in Language Teaching: An Anthology of Current Practice. Cambridge: Cambridge University Press, 2003.

[2] Anker and Susan, Real Writing with Readings Paragraph and Essays for College, Work, and Everyday Life Fifth Edition. New York: Bedford St. Martin's, 2010.

[3] Zemach, D. E, and L. A. Rumisek, Academic Writing from Paragraph to Essay. Oxford. MacMillan Education, 2005.

[4] Folse, K. S, A. Muchmore-Vokoun, E. V. Solomon, Writing, and Great, Great Essays Fourth Edition. New York: Cengage Learning, 2014.

[5] Sihombing and P. And, "The Effect of Applying Think Talk Write Strategy on Students' Achievement in Writing Descriptive Text," vol. 4, 2015.

[6] Shiach and Don, How to Write Essay A Step by step Guide for all Levels, with sample essays. Oxford: How to Content, 2007.

[7] N. Murray, Writing Essays in English Language and Linguistics: Principles, Tips, and Strategies for Undergraduates. Cambridge: Cambridge University Press, 2012.

[8] E. Babin and K. Harrison, Contemporary Composition Studies A Guide to Theories and terms. New York: Greenwood Press, 1999.

[9] V. W., B. and T. L., and Richards, Brain Literacy for Educators and Psychologists. New York: Academic Press, 2002.

[10] R. R. Mandal, "'Cooperative Learning Strategies to Enhance Writing Skill,' The Modern Journal of Applied Linguistics," vol. 1, pp. 94-102, 2009.

[11] Siddique, Muhammad, M. Kaur, and S. Singh, "Effectiveness of Cooperative Learning in Enhancing Students' Essay Writing Skills in Pakistani Colleges," Int. J. Humanit. Soc. Sci., vol. 05, no. 8, pp. 68-70, 2016.

[12] Fatimawati and Ida, "Interrelated Influence of Internal and External Factors on Malaysian Learners' Self-concept in Academic Writing," J. ASIA TEFL, vol. 12, no. 1, pp. 79-115, 2015.

[13] Rahimia, Ali, and J. Qannadzadeh, "Quantitative ? usage of logical connectors? in Iranians' EFL Essay writing and logical and linguistic intelligence," Procedia Soc. Behav. Sci., vol. 5, pp. 2012-2019, 2010.

[14] S. Khonsari, "Approaches to Content-Based Academic Writing," J. ASIA TEFL, vol. 02, no. 02, pp. 117-137, 2005. 